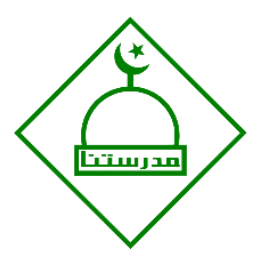

\title{
KESIAPAN MAHASISWA PGSD UNTUK MENJADI GURU SD
}

\author{
Yogi Kuncoro Adi \\ Pendidikan Guru Sekolah Dasar, Fakultas Keguruan dan Ilmu Pendidikan, Universitas Kuningan, \\ Kuningan, Indonesia
}

\begin{abstract}
The better higher education gained by students is expected to make prospective teachers have a great teacher competency. This study aims to determine and describe the readiness of students to become primary school teachers by cognitive readiness, emotive-attitudinal readiness, and behavioral readiness. The subjects of this study were the students of Primary Education at the University of Kuningan by the 2016/2017 Academic Year. The object of this study was the readiness to be an primary school teacher by cognitive readiness, emotiveattitudinal readiness, and behavioral readiness. This research was survey research with a quantitative approach. The population was all Primary Education students at University of Kuningan. Samples were taken by purposive sampling technique. The technique of collecting data was measured by a closed and open questionnaire. The data analysis technique used in this study was percentage techniques with the editing, scoring, and tabulation stages. The results showed that Primary Education students at University of Kuningan were ready to get primary school teachers as a profession. Behavioral aspects of readiness still need attention in order to obtain maximum results. By overall aspects, the readiness still not gain the maximum category (Very Ready) for each indicator in this study. In addition, there are some urgent issues that require an action, such as student motivation in choosing the teaching profession and working for salary only.
\end{abstract}

Keywords: readiness, teacher competencies, prospective teacher

\begin{abstract}
ABSTRAK
Semakin baik pendidikan tinggi yang diperoleh mahasiswa diharapkan menjadikan calon guru sarat dengan kompetensi keguruan yang dimiliki. Penelitian ini bertujuan untuk mengetahui dan mendeskripsikan kesiapan mahasiswa untuk menjadi guru SD ditinjau dari aspek cognitive readiness, emotiveattitudinal readiness, dan behavioral readiness. Subjek penelitian ini adalah mahasiswa PGSD FKIP Universitas Kuningan Tahun Ajar 2016/2017. Objek penelitian ini adalah kesiapan untuk menjadi guru SD ditinjau dari aspek cognitive readiness, emotive-attitudinal readiness, dan behavioral readiness. Penelitian ini merupakan penelitian survei dengan pendekatan kuantitatif. Populasi adalah seluruh mahasiswa PGSD FKIP Universitas Kuningan. Sampel diambil dengan teknik purposive sampling. Teknik pengumpulan data kesiapan menjadi guru SD diukur dengan angket tertutup dan terbuka. Teknik analisis data yang digunakan dalam penelitian ini adalah menggunakan teknik persentase dengan tahap editing, skoring, dan tabulasi. Hasil penelitian menunjukkan mahasiswa PGSD FKIP Universitas Kuningan Siap untuk mengemban profesi Guru SD. Aspek behavioral readiness masih harus mendapat perhatian agar memperoleh hasil yang maksimal. Secara keseluruhan aspek, kesiapan tersebut juga masih belum dalam kategori maksimal (Sangat Siap) untuk setiap indikator dalam penelitian ini. Selain itu, beberapa permasalahan urgen yang segera membutuhkan penanganan seperti motivasi mahasiswa dalam memilih profesi guru dan bekerja sepenuh gaji.
\end{abstract}

Kata-kata Kunci: kesiapan, kompetensi guru, calon guru

\section{PENDAHULUAN}

Perkembangan zaman merupakan suatu tantangan bagi sebuah bangsa dalam menghadapi arus globalisasi yang menghilangkan batas geografis, tidak terkecuali Indonesia. Perkembangan ini berdampak pada semua aspek termasuk ilmu pengetahuan dan teknologi. Perkembangan ilmu pengetahuan dan 
teknologi berimbas pada tuntutan terhadap peningkatan kualitas sumber daya manusia. Salah satu cara untuk menjamin kualitas sumber daya manusia adalah melalui pendidikan yang berkualitas. Demi mencapai pendidikan berkualitas haruslah melibatkan para praktisi, akademisi, dan kebijakan pemerintah dalam lingkup pendidikan-pun juga ikut berkontribusi dalam membentuk Generasi Emas Indonesia

Pengembangan sumber daya manusia haruslah dipetakan agar memudahkan dalam mengetahui kondisi real sumber daya manusia untuk mempermudah menemukan solusi dalam peningkatan kualitas SDM. Berdasar nilai rerata Programme for International Student Assessment (PISA) tahun 2012 seperti dikutip oleh Tobias et al (2014: 15), prestasi Indonesia masih rendah dibanding rerata 72 negara. Hal tersebut terlihat dari data tingkat kemampuan Indonesia pada matematika mencapai skor 375, kemampuan membaca pada skor 395, dan sains pada skor 380. Hasil survei tersebut menandakan bahwa kualitas SDM masih rendah.

Kualitas SDM yang rendah membutuhkan penanganan yang tepat. Salah satu penanganan dalam rangka meningkatkan kualitas SDM adalah melalui pendidikan yang berkualitas. Pendidikan dalam proses pelaksanaannya tidak dapat lepas dari pembelajaran. Pembelajaraan terdiri dari berbagai komponen yang dijadikan penjamin ketercapaian tujuan pendidikan. Komponen dalam pembelajaran memiliki hubungan saling timbal balik. Komponen pembelajaran yang tidak dapat digantikan salah satunya adalah guru sebagai praktisi.

Guru yang dikatakan kompeten apabila memiliki empat kompetensi secara menyeluruh. Kompetensi seorang guru dalam melaksanakan tugasnya termaktub dalam Undang-undang Guru dan Dosen No 14 Tahun 2005 Pasal 10 Ayat 1 meliputi kompetensi pedagogik, kompetensi kepribadian, kompetensi sosial, dan kompetensi profesional yang diperoleh melalui pendidikan profesi. Hal tersebut berarti bahwa seorang guru dapat disebut guru yang berkompeten apabila memiliki keempat kompetensi tersebut di dalamnya dan dapat dibuktikan secara otentik.

Hasil penelitian survei oleh Fahdini dkk (2014: 33) menghasilkan temuan analisis rating scale yang menunjukan bahwa kompetensi profesional guru tersertifikasi di kabupaten Sumedang, empat aspek berada pada kategori “cukup" dan satu aspek berada pada kategori "kurang”. Aspek yang mendapatkan kategori cukup meliputi aspek penguasaan terhadap: (1) SK dan KD mata pelajaran/bidang pengembangan, (2) materi pembelajaran yang kreatif, (3) teknologi informasi dan komunikasi untuk berkomunikasi dan mengembangkan diri, dan (4) materi, struktur, konsep, dan pola pikir keilmuan. Sedangkan aspek yang berkategori kurang adalah mengembangkan keprofesionalan secara berkelanjutan dengan melakukan tindakan reflektif. Berdasarkan penelitian ini, dapat dimaknai bahwa kompetensi guru yang sudah bersertifikat pendidik belum tentu dapat dikatakan siap. Oleh karena itu, kesiapan akan kompetensi tersebut harus sudah diasah dengan intens sejak menjadi mahasiswa calon guru. 
Kesiapan guru dapat dimiliki dari pendidikan yang diperolehnya sejak menjadi mahasiswa. Pendidikan tinggi merupakan jawaban untuk menciptakan SDM yang profesional dalam perannya bermasyarakat. Semakin baik pendidikan yang diperoleh mahasiswa diharapkan menjadikan calon guru sarat dengan kompetensi keguruan yang dimiliki. Oleh karena itu, kesiapan mahasiswa calon guru sangat berdampak signifikan dalam kemajuan pendidikan di Indonesia.

Besides dalam Jusoh (2012: 99) menemukan bahwa "teachers readiness and suitable teaching approaches had a highly significant relationship to the levels of student motivation, academic achievement and overall perception on the effectiveness of the lessons". Pentingnya kesiapan dan pengajaran guru yang sesuai pendekatan memiliki hubungan sangat signifikan terhadap tingkat motivasi siswa, prestasi akademik, dan persepsi keseluruhan terhadap efektivitas pelajaran. Oleh karena itu, temuan tersebut menandakan betapa pentingnya kesiapan guru. Dalam hal ini, kesiapan guru berdampak signifikan pada siswa yang pada akhirnya adalah tercapainya tujuan pendidikan. Kesiapan merupakan variabel penting yang harus selalu diasah oleh mahasiswa calon guru.

Bandura dalam Maddox, Forte, \& Boozer (2000: 276) menggambarkan sebuah model pembelajaran sosial dasar yang digambarkan seperti di atas. Melalui model ini, hubungan langsung dan timbal balik antara domain cognitive, emotive-attitudinal, dan behavioral individu terlihat jelas. Sederhananya, determinisme timbal balik menunjukkan bahwa masing-masing domain dipengaruhi oleh dan mempengaruhi setiap domain lainnya dalam individu.

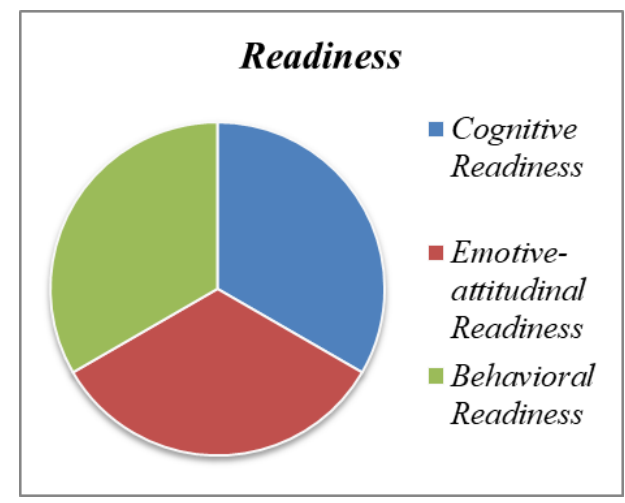

\section{Gambar 1. Skema Konsep Kesiapan Bandura}

\section{Sumber: Maddox, Forte, \& Boozer, 2000}

Lebih lanjut, berdasarkan skema di atas, Maddox, Forte, \& Boozer (2000: 277) menjabarkan ketiga domain dari aspek kesiapan. Hal tersebut meliputi: (1) cognitive readiness, mencakup kemampuan berpikir kognitif dan kritis, sadar kekuatan dan keterbatasan diri, mudah membuat koneksi antara pembelajaran di kelas dan aplikasi dunia nyata, sadar nilai-nilai pribadi dan bersedia untuk mengungkapkan dalam proses pembelajaran, mampu mengintegrasikan konsep-konsep dan alat-alat dari berbagai disiplin ilmu; (2) emotive-attitudinal readiness, mencakup siap untuk memikul tanggung jawab dalam pembelajaran, antusias tentang belajar, bersedia untuk beradaptasi dengan alam, kemandirian dalam belajar, menghargai nilai 
intrinsik dari pembelajaran; dan (3) behavioral readiness, mencakup bersedia untuk berfungsi dalam kemitraan dengan rekan-rekan belajar dan fasilitator, serta mahir mengorganisir tuntutan waktu untuk mencapai tujuan pembelajaran.

Kesiapan mahasiswa untuk menjadi guru yang berkompeten membutuhkan persiapan dari usahausaha yang relevan. Usaha yang ditempuh adalah mempersiapkan pengetahuan, keterampilan, dan perilaku untuk dikuasai sebagai prasyarat dalam melaksanakan tugas keprofesionalan. Penguasaan ketiga aspek tersebut diwujudkan ke dalam keempat kompetensi keguruan, yang mana mereka mendapatkannya ketika belajar empat tahun di suatu lembaga pendidikan. Pemerintah mendeskripsikan kompetensi keguruan mencakup kompetensi pedagogik, kepribadian, profesional, dan sosial. Peraturan Pemerintah Nomor 19 Tahun 2005 Pasal 28 Ayat 3 disebutkan bahwa; (1) Kompetensi pedagogik adalah kemampuan mengelola pembelajaran peserta didik yang meliputi pemahaman terhadap peserta didik, perancangan dan pelaksanaan pembelajaran, evaluasi hasil belajar, dan pengembangan peserta didik untuk mengaktualisasikan berbagai potensi yang dimilikinya; (2) Kompetensi kepribadian adalah kemampuan kepribadian yang mantap, stabil, dewasa, arif, dan berwibawa, menjadi teladan bagi peserta didik, dan berakhlak mulia; (3) Kompetensi profesional adalah adalah kemampuan penguasaan materi pembelajaran secara luas dan mendalam yang memungkinkannya membimbing peserta didik memenuhi standar kompetensi yang ditetapkan dalam Standar Nasional Pendidikan; (4) Kompetensi sosial adalah kemampuan pendidik sebagai bagian dari masyarakat untuk berkomunikasi dan bergaul secara efektif dengan peserta didik, sesama pendidik, tenaga kependidikan, orangtua/wali peserta didik, dan masyarakat sekitar.

Permasalahan guru dan atau calon guru begitu kompleks. Sehingga, pemerintah dan lembaga pendidikan harus saling berjalan beriringan kaitannya dengan penyedia tenaga keguruan. PGSD FKIP Universitas Kuningan merupakan salah satu penyedia tenaga keguruan di tingkat sekolah dasar yang memiliki andil dalam menyiapkan guru SD yang berkompeten. Keberhasilan PGSD FKIP Universitas Kuningan dalam menyiapkan guru SD yang berkompeten juga tergantung pada proses yang dilalui para mahasiswa selama pembelajaran. Dalam pelaksanaannya, sampai saat ini belum pernah diketahui bagaimana kesiapan mahasiswa PGSD menjadi seorang guru selama menempuh pembelajaran di Universitas Kuningan. Oleh karena itu, penelitian yang diambil adalah untuk mengungkap kesiapan mahasiswa menjadi guru SD yang berkompeten.

\section{METODE PENELITIAN}

Jenis Penelitian 
Penelitian ini menggunakan desain evaluasi dan pendekatan kuantitatif dengan jenis survei. Penelitian evaluasi ini bermaksud untuk mengetahui kesiapan mahasiswa PGSD untuk menjadi guru yang berkompeten.

Tempat dan Waktu Penelitian

Penelitian ini dilaksanakan di kampus 1 PGSD FKIP Universitas Kuningan. Waktu penelitian ini dilaksanakan sekitar bulan Mei-Juni 2017.

Populasi dan Sampel Penelitian

Keseluruhan mahasiswa PGSD FKIP Universitas Kuningan yang berjumlah 795 orang merupakan populasi dalam penelitian ini. Teknik yang digunakan adalah purposive sampling yang mana subjek ditentukan oleh peneliti sebanyak 82 orang.

Teknik dan Instrumen Pengumpulan Data

Teknik pengumpulan data yang digunakan dalam penelitian ini adalah angket/kuesioner. Selain itu, peneliti menggunakan wawancara oleh karena dirasa perlu sebagai instrumen pendukung terhadap angket tertutup.

Validitas dan Reliabilitas Instrumen

Validasi isi pernyataan/pertanyaan ditentukan atas dasar pertimbangan (expert judgment) dari para ahli.

Teknik Analisis Data

Teknik analisis data yang diperoleh dari angket, pengolahan datanya dilakukan melalui tahapantahapan: (1) Editing, yang mana peneliti harus dapat memastikan bahwa responden telah mengisi dengan lengkap seluruh pernyataan dalam angket; (2) Skoring, yang mana pengukuran dan pengumpulan data dilakukan dengan memberikan skor atas jawaban responden pada setiap butir, kemudian menjumlahkan untuk semua butir; (3) Tabulasi, yang mana data yang telah diklasifikasikan sesuai dengan kelompoknya kemudian ditabulasikan ke dalam tabel. Selanjutnya data hasil angket dihitung bobot nilainya sesuai dengan kriteria.

\section{HASIL DAN PEMBAHASAN}

Hasil Penelitian 
Berikut ini disajikan tabel persentase setiap aspek kesiapan yang diteliti pada mahasiswa PGSD FKIP Universitas Kuningan.

Tabel 1. Persentase Setiap Aspek Kesiapan

\begin{tabular}{lccc}
\hline \multicolumn{1}{c}{ Kriteria } & $\begin{array}{c}\text { Nilai Skor } \\
\text { Jawaban }\end{array}$ & Persentase (\%) & Kategori \\
\hline Cognitive & 2418 & 81,91 & Sangat Siap \\
Emotive-Attitudinal & 2599 & 79,24 & Sangat Siap \\
Behavioral & 1481 & 75,25 & Siap \\
Total & $\mathbf{6 4 9 8}$ & $\mathbf{7 9 , 2 4}$ & Sangat Siap
\end{tabular}

Sumber: Hasil Penelitian, 2017

Berdasarkan tabel di atas, diperoleh hasil persentase cognitive untuk mahasiswa PGSD FKIP Universitas Kuningan adalah sebesar 81,91\%, persentase emotive-attitudinal sebesar 79,24\% dan persentase behavioral sebesar 75,25\%. Persentase yang didapatkan tersebut di atas menunjukkan bahwa kesiapan mahasiswa PGSD untuk menjadi Guru SD dikategorikan Sangat Siap.

Berikut ini disajikan tabel persentase kesiapan yang diteliti pada masing-masing tingkat mahasiswa PGSD FKIP Universitas Kuningan.

Tabel 2. Persentase Kesiapan Mahasiswa Tiap Tingkat

\begin{tabular}{cccc}
\hline Kriteria & $\begin{array}{c}\text { Nilai Skor } \\
\text { Jawaban }\end{array}$ & Persentase (\%) & Kategori \\
\hline Tingkat 4 & 2317 & 77,23 & Sangat Siap \\
\hline Tingkat 3 & 1597 & 79,85 & Sangat Siap \\
Tingkat 2 & 1667 & 83,35 & Sangat Siap \\
Tingkat 1 & 917 & 76,42 & Sangat Siap \\
Total & $\mathbf{6 4 9 8}$ & $\mathbf{7 9 , 2 4}$ & Sangat Siap \\
\hline
\end{tabular}

Sumber: Hasil Penelitian, 2017

Berdasarkan di atas, diperoleh hasil persentase kesiapan mahasiswa PGSD untuk menjadi Guru SD. Persentase tersebut di atas menunjukkan bahwa pada setiap tingkat, mahasiswa memiliki kategori kesiapan pada tingkat Sangat Siap, bahkan kategori tersebut berlaku pada tingkat satu Program Studi.

Berikut ini disajikan tabel persentase cognitive readiness pada mahasiswa PGSD FKIP Universitas Kuningan secara umum 
Tabel 3. Cognitive Readiness Mahasiswa PGSD

\begin{tabular}{|c|c|c|c|}
\hline Kriteria & $\begin{array}{c}\text { Nilai Skor } \\
\text { Jawaban }\end{array}$ & Persentase $(\%)$ & Kategori \\
\hline $\begin{array}{l}\text { Kemampuan } \\
\text { berpikir kognitif } \\
\text { dan kritis }\end{array}$ & 1028 & 78,35 & Sangat Siap \\
\hline $\begin{array}{l}\text { Menyadari } \\
\text { kekuatan dan } \\
\text { keterbatasan diri }\end{array}$ & 267 & 81,40 & Sangat Siap \\
\hline $\begin{array}{l}\text { Mampu membuat } \\
\text { koneksi antara } \\
\text { pembelajaran di } \\
\text { kelas dan aplikasi } \\
\text { dunia nyata }\end{array}$ & 257 & 78,35 & Sangat Siap \\
\hline $\begin{array}{l}\text { Menyadari nilai- } \\
\text { nilai pribadi dan } \\
\text { bersedia untuk } \\
\text { mengungkapkan } \\
\text { dalam proses } \\
\text { pembelajaran }\end{array}$ & 293 & 89,33 & Sangat Siap \\
\hline $\begin{array}{l}\text { Mampu } \\
\text { mengintegrasikan } \\
\text { konsep-konsep dan } \\
\text { alat-alat dari } \\
\text { berbagai disiplin } \\
\text { ilmu }\end{array}$ & 573 & 87,35 & Sangat Siap \\
\hline Total & 2418 & 81,91 & Sangat Siap \\
\hline
\end{tabular}

Sumber: Hasil Penelitian, 2017

Berdasarkan tabel yang disajikan di atas, secara umum dan mayoritas, cognitive readiness mahasiswa termasuk dalam kategori Sangat Siap. Meskipun begitu peneliti mencoba mengungkapnya hingga tingkat soal. Butir soal 24 indikator Kemampuan berpikir kognitif dan kritis berkategori Siap dengan persentase 63,41. Hal tersebut menandakan bahwa mahasiswa kurang setuju dalam pemberian evaluasi belajar pada siswa dengan teknik multiple choice (pilihan ganda) saja.

Berikut ini disajikan tabel persentase emotive-attitudinal readiness pada mahasiswa PGSD FKIP Universitas Kuningan secara umum.

Tabel 4. Emotive-attitudinal Readiness Mahasiswa PGSD

\begin{tabular}{|c|c|c|c|}
\hline Kriteria & $\begin{array}{l}\text { Nilai Skor } \\
\text { Jawaban }\end{array}$ & Persentase $(\%)$ & Kategori \\
\hline $\begin{array}{lr}\text { Siap } & \text { untuk } \\
\text { memikul } & \text { tanggung } \\
\text { jawab } & \text { dalam } \\
\text { pembelajaran }\end{array}$ & 1015 & 77,36 & Sangat Siap \\
\hline $\begin{array}{l}\text { Antusias dalam } \\
\text { belajar }\end{array}$ & 527 & 80,34 & Sangat Siap \\
\hline $\begin{array}{l}\text { Bersedia } \\
\text { menyesuaikan diri }\end{array}$ & 571 & 87,04 & Sangat Siap \\
\hline $\begin{array}{ll}\text { Menghargai } & \text { nilai } \\
\text { intrinsik } & \text { dari } \\
\text { pembelajaran } & \end{array}$ & 486 & 74,09 & Siap \\
\hline Total & 2599 & 79,24 & Sangat Siap \\
\hline
\end{tabular}




\section{Sumber: Hasil Penelitian, 2017}

Berdasarkan tabel yang disajikan di atas, secara umum dan mayoritas, emotive-attitudinal readiness mahasiswa termasuk dalam kategori Sangat Siap. Meskipun begitu peneliti mencoba mengungkapnya hingga tingkat soal. Butir soal 19 pada indikator Siap untuk memikul tanggung jawab dalam pembelajaran berada pada persentase 47,26 dengan kategori Kurang Siap. Hal tersebut menandakan bahwa mahasiswa sebagai calon guru nantinya akan bekerja dengan usaha yang sepadan dengan gaji yang diterima. Selain itu, pada butir soal 4 dengan indikator Menghargai nilai intrinsik dari pembelajaran berpersentase 64,33 dengan kategori Siap. Hal tersebut menandakan bahwa mahasiswa setuju kegiatan memfasilitasi siswa dalam menyimpulkan materi yang telah dipelajari adalah penting.

Berikut ini disajikan tabel persentase behavioral readiness pada mahasiswa PGSD FKIP Universitas Kuningan secara umum.

Tabel 5. Behavioral Readiness Mahasiswa PGSD

\begin{tabular}{|c|c|c|c|}
\hline Kriteria & $\begin{array}{c}\text { Nilai Skor } \\
\text { Jawaban }\end{array}$ & Persentase $(\%)$ & Kategori \\
\hline $\begin{array}{l}\text { Bersedia menjalin } \\
\text { kemitraan, } \\
\text { berkomunikasi, } \\
\text { dan bergaul secara } \\
\text { efektif }\end{array}$ & 1039 & 79,19 & Sangat Siap \\
\hline $\begin{array}{l}\text { Mahir } \\
\text { mengorganisir } \\
\text { tuntutan waktu } \\
\text { untuk mencapai } \\
\text { tujuan } \\
\text { pembelajaran }\end{array}$ & 442 & 67,38 & Siap \\
\hline Total & 1481 & 75,25 & Siap \\
\hline
\end{tabular}

Sumber: Hasil Penelitian, 2017

Berdasarkan tabel yang disajikan di atas, secara umum dan mayoritas, behavioral readiness mahasiswa termasuk dalam kategori Siap. Peneliti mencoba mengungkapnya hingga tingkat soal. Butir soal 13 dan 23 dengan indikator Bersedia menjalin kemitraan, berkomunikasi, dan bergaul secara efektif berpersentase 75,30 dan 75,61 secara berturut-turut dengan kategori Siap. Hal tersebut menandakan bahwa mahasiswa cukup memahami tahap perkembangan siswa SD dan mampu merancang pembelajaran sesuai dengan tahap perkembangan mereka. Selain itu, mahasiswa juga setuju bahwa dengan mengikuti organisasi tidak akan menghambat pekerjaan/ perkuliahan.

Butir soal 22 dan 12 dengan indikator Mahir mengorganisir tuntutan waktu untuk mencapai tujuan pembelajaran berpersentase 68,90 dan 65,85 dengan kategori Siap. Hal tersebut menandakan bahwa 
mahasiswa setuju bahwa salah satu tugas guru adalah penelitian. Selain itu, mahasiswa juga siap dalam menyelesaikan tugas yang diberikan sesuai dengan deadline.

Kesiapan mahasiswa PGSD untuk menjadi guru SD juga dianalisis dari hasil wawancara yang dilakukan. Hasil wawancara kesiapan yang ditinjau dari aspek cognitive, emotive-attitudinal, dan behavioral menunjukkan hasil sebagai berikut.

Berdasarkan beberapa permasalahan yang ditemukan dari kesiapan cognitive: (a) Mahasiswa kurang setuju dalam pemberian evaluasi belajar pada siswa dengan teknik multiple choice (pilihan ganda) saja; dan (b) Pemahaman selama proses perkuliahan terhadap mata kuliah kependidikan mempengaruhi kesiapan

Berdasarkan beberapa permasalahan yang ditemukan dari kesiapan emotive-attitudinal: (a) Mahasiswa setuju kegiatan memfasilitasi siswa dalam menyimpulkan materi yang telah dipelajari adalah penting; (b) Beberapa mahasiswa belum memiliki cita-cita mulia untuk menjadi seorang guru ketika mengambil program studi ini; dan (c) Mahasiswa sebagai calon guru nantinya akan bekerja dengan usaha yang sepadan dengan gaji yang diterima, hal tersebut melihat penggajian guru honorer

Berdasarkan beberapa permasalahan yang ditemukan dari kesiapan behavioral: (a) Mahasiswa cukup memahami tahap perkembangan siswa SD dan cukup mampu merancang pembelajaran sesuai dengan tahap perkembangan mereka; (b) Mahasiswa setuju bahwa dengan mengikuti organisasi tidak akan menghambat pekerjaan/perkuliahan; (c) Mahasiswa setuju bahwa salah satu tugas guru adalah penelitian; dan (d) Mahasiswa siap dalam menyelesaikan tugas yang diberikan sesuai dengan deadline

\section{Pembahasan}

Berbagai permasalahan yang telah ditemukan berdasarkan hasil penelitian yang telah tersebut di atas terdapat permasalahan yang perlu perbaikan dan ada pula yang cukup ditingkatkan. Permasalahan yang memerlukan perbaikan merupakan permasalahan yang urgen untuk dikembangkan dikarenakan berada di bawah kategori Siap. Sedangkan permasalahan yang hanya cukup ditingkatkan dikarenakan terdapat beberapa indikator yang berada pada kategori Siap diharapkan dapat dikembangkan menjadi Sangat Siap.

Pengembangan kesiapan mahasiswa PGSD dari kategori Siap menjadi Sangat Siap dalam permasalahan yang ditemukan dalam penelitian ini mencakup 10 prinsip pengajaran efektif (Slavin, 2011: 31). Prinsip-prinsip tersebut meliputi: (1) pengetahuan tentang pokok mata pelajaran; (2) pengetahuan tentang perkembangan dan pembelajaran manusia; (3) penyesuaian pengajaran dengan kebutuhan individu; (4) berbagai strategi pengajaran; (5) motivasi dan pengelolaan ruang kelas; (6) kemampuan komunikasi; (7) kemampuan perencanaan pengajaran; (8) penilaian pembelajaran siswa; (9) komitmen dan tanggung jawab profesional; serta (10) kemitraan. Pemantapan kembali terhadap materi tersebut dalam ruang perkuliahan diharapkan akan meningkatkan kesiapan mahasiswa PGSD FKIP Universitas 
Kuningan menjadi Sangat Siap. Hal tersebut sejalan dengan bahwa pemahaman selama proses perkuliahan terhadap mata kuliah kependidikan mempengaruhi kesiapan mahasiswa keguruan untuk siap menjadi guru.

Beberapa mahasiswa belum memiliki cita-cita mulia untuk menjadi seorang guru ketika mengambil program studi ini. Akan tetapi, hasrat tersebut diharapkan dapat berkembang ke arah yang positif dengan selalu memberikan motivasi kepada mahasiswa tentang alasan untuk mengajar dan mengambil profesi keguruan. Ornstein, Levine, \& Gutek (2011: 3) menyebutkan motivasi untuk menjadi guru dapat termasuk: (1) love of children; (2) desire to impart knowledge; (3) interest in and excitement about teaching; (4) desire to perform a valuable service to society; (5) job security; (6) pension benefits; or (7) relative ease in preparing for teaching compared with the training required by some other professions. Harapannya, pemberian motivasi tersebut dapat mengubah mindset mahasiswa untuk menerima dan mencintai profesi yang mereka akan ambil nantinya.

Permasalahan yang paling urgen ditemukan dalam penelitian ini adalah bahwa mahasiswa sebagai calon guru nantinya akan bekerja dengan usaha yang sepadan dengan gaji yang diterima, hal tersebut melihat penggajian guru honorer. Temuan ini dapat dijelaskan melalui teori kesetaraan (Hoy \& Miskel, 2014: 232) bahwa apabila rasio input/outputnya kira-kira sama dengan rasio input/output orang-orang yang menjadi subjek perbandingan kita, maka kita memandang perlakuan yang kita terima sebagai adil. Berdasarkan hal tersebut, konsekuensi potensial yang akan timbul adalah menurunnya motivasi. Akan tetapi, perasaan tersebut dapat juga dikurangi dengan tiga cara, yaitu dengan mencoba meningkatkan hasil-hasil kerjanya, meninggalkan pekerjaan, atau mengurangi inputnya. Oleh karena itu, berdasarkan temuan ini dapat disimpulkan istilah "mendidik sepenuh hati atau sepenuh gaji", dikarenakan pada momen inilah jiwa seorang pendidik (guru) akan diuji.

Hasil analisis yang diperoleh dari angket dan wawancara secara keseluruhan menunjukkan bahwa mahasiswa PGSD FKIP Universitas Kuningan Siap untuk menjadi Guru SD. Akan tetapi, kesiapan tersebut masih belum dalam kategori maksimal (Sangat Siap) untuk setiap indikator dalam penelitian ini. Oleh karena itu, diharapkan hal tersebut dapat dikembangkan lagi selama proses pendidikan di kampus. Selain itu, beberapa permasalahan urgen yang segera membutuhkan penanganan seperti motivasi mahasiswa dalam memilih profesi guru dan bekerja sepenuh gaji.

\section{SIMPULAN}

Berdasarkan hasil penelitian yang dilakukan pada mahasiswa PGSD di lingkungan FKIP Universitas Kuningan dalam kesiapannya untuk menjadi Guru SD, mahasiswa Siap untuk mengemban profesi ini. Aspek behavioral readiness masih harus mendapat perhatian agar memperoleh hasil yang maksimal. Secara keseluruhan aspek, kesiapan tersebut juga masih belum dalam kategori maksimal (Sangat Siap) untuk 
setiap indikator dalam penelitian ini. Selain itu, beberapa permasalahan urgen yang segera membutuhkan penanganan seperti motivasi mahasiswa dalam memilih profesi guru dan bekerja sepenuh gaji.

Berdasarkan kesimpulan tersebut, maka diharapkan segenap keluarga Prodi PGSD saling bekerjasama demi penyempurnaan kesiapan para mahasiswa calon guru SD. Hal tersebut berimplikasi terhadap efisiensi dan efektivitas pembelajaran pada mata kuliah yang bersangkutan dan kegiatan penunjang akademik lainnya, forum diskusi misalnya.

\section{DAFTAR PUSTAKA}

Fahdini, R., Mulyadi, E., Suhandani, D., \& Julia. (2014). Identifikasi kompetensi guru sebagai cerminan profesionalisme tenaga pendidik di kabupaten Sumedang. Mimbar Sekolah Dasar, 1 (1), 33-42.

Jusoh, R. (2012). Effects of teachers "e readiness in teaching and learning of entrepreneurship education in primary schools. International Interdisciplinary Journal of Education, 1 (7), 98-102.

Maddox, N., Forte, M., \& Boozer, R. (2000). Learning readiness: an underappreciated yet vital dimension in experiential learning. Developments in Business Simulation \& Experiential Learning, 27, 272-278.

Ornstein, A. C., Levine, D. U., \& Gutek, G. L. (2011). Foundations of education. California: Cengage Learning.

Presiden RI. (2005). Undang-undang Republik Indonesia Nomor 14 Tabun 2005 tentang Guru dan Dosen.

Slavin, R. E. (2011). Psikologi pendidikan teori dan praktik edisi kesembilan jilid 1. Jakarta: Indeks.

Tobias, J., Wales. J., Syamsulhakim, E., \& Suharti. (2014). Towards better education quality Indonesia's promising path. London: Overseas Development Institute. 